\title{
KEAMANAN JARINGAN MENGGUNAKAN UNIFIED THREAT MANAGEMENT PADA SERVER BERBASISKAN LINUX
}

\author{
Bambang Heru'; Benny'; Defendy ${ }^{3}$; Wahyu Hento ${ }^{4}$ \\ 1, 2, 3, ${ }^{3}$ Jurusan Teknik Informatika, Fakultas Ilmu Komputer, Universitas Bina Nusantara, \\ Jl. K.H. Syahdan No. 9, Kemanggisan/Palmerah, Jakarta Barat 11480 \\ 1bambang@inn.bppt.go.id
}

\begin{abstract}
UTM is an application which integrated many security features become a single hardware platform. The reason behind this research is to build a system that protects the network in St. Bellarminus school. Research method that has been used in this research is spiral method, whereas the development of the application is continues and can be modified easily if there is new version of the security tools implemented in the application, or if there is a better security tools to be used. The outcome of the system is very good, because it can protects the network: cross-platform firewall, Intrusion Detection System, Proxy Server, email protection against virus and spam. In conclusion, the application can produce high effectiveness with low cost and this application is very useful in monitoring and configuring the network in St. Bellarminus school.
\end{abstract}

Keywords: security network, unified threat management, anti virus, server, proxy, firewall

\begin{abstract}
ABSTRAK
UTM adalah suatu aplikasi yang mengintegrasikan berbagai fitur keamanan menjadi suatu platform hardware tunggal. Alasan pembangunan sistem ini adalah untuk memberikan proteksi menyeluruh pada jaringan di sekolah St. Bellarminus. Metode yang digunakan adalah metode spiral dimana pengembangan aplikasi ini akan bersifat berkelanjutan dan dapat dengan mudah diubah jika ada versi terbaru dari tools keamanan yang digunakan dalam aplikasi atau jika ada tools keamanan yang lebih baik. Hasil yang diberikan oleh aplikasi ini dapat dikatakan sangat baik karena memberikan proteksi jaringan, yaitu cross-platform firewall, Intrusion Detection System, Proxy Server, dan Proteksi terhadap -e-mail yang mengandung virus dan spam. Simpulan yang dapat ditarik dari aplikasi ini adalah aplikasi ini dapat menghasilkan efektivitas kerja yang lebih dengan biaya rendah dan aplikasi ini sangat berguna dalam memantau kondisi jaringan dan mengkonfigurasi jaringan di sekolah St. Bellarminus.
\end{abstract}

Kata kunci: keamanan jaringan, unified threat management, anti virus, server, proxy, firewall

\section{PENDAHULUAN}

Saat ini, media internet sudah digunakan secara luas dalam organisasi dan perusahaan. Akses dan transfer data pun dilakukan dengan mudah dan cepat. Akan tetapi dibalik itu, muncul isu keamanan jaringan yang dirasakan sangat berpengaruh terhadap perkembangan internet. Sistem jaringan yang terhubung ke internet memerlukan pengamanan yang lebih baik mengingat pemakaiannya yang juga cukup luas sehingga mengakibatkan tingkat ancaman yang juga tinggi. Beberapa ancaman muncul di internet, seperti virus, penyusupan jaringan, pencurian, perusakan, dan penyalahgunaan data. Pemanfaatan internet juga banyak disalahgunakan oleh pengguna sendiri. Dampak negatif seperti pornografi, kekerasan, perjudian, dan SARA juga menjadi permasalahan tersendiri.
Sistem pengamanan yang dapat menangani ancaman dari pihak luar melalui jaringan internet menjadi suatu hal yang mutlak dimiliki sebuah perusahaan atau organisasi. Dibalik itu, pengawasan atas pengguna koneksi internet dalam organisasi tersebut juga harus diperhatikan. Akses berlebih yang diberikan kepada pengguna akan mengakibatkan penyimpangan di luar kepentingan organisasi. Dalam hal ini, diperlukan pembatasan hak akses pengguna ke situs berisiko dan yang tidak diperkenankan oleh pihak organisasi.

Yayasan St. Bellarminus merupakan sebuah yayasan yang bergerak di bidang pendidikan dan menggunakan koneksi internet dalam kegiatan pembelajaran dan merupakan fasilitas untuk akses informasi bagi para guru dan siswa. Untuk itu, sistem pengamanan dan kontrol pengguna sangat diperlukan untuk mendukung kelancaran operasional dan kegiatan belajar mengajar. Saat tulisan ini dibuat, 
Yayasan St. Bellarminus belum memiliki sistem keamanan jaringan, pemantauan jaringan, dan pembatasan hak akses pengguna ke internet.

Berdasarkan kondisi tersebut, dibutuhkan sebuah solusi sistem keamanan yang dapat melindungi data jaringan internal yayasan dari ancaman dan serangan dari luar. Sistem keamanan juga perlu dapat di-monitor dan di-manage oleh seorang administrator yang diberikan kewenangan terhadap sistem ini. Sistem diharapkan dapat bekerja dengan baik sehingga pengamanan jaringan dapat mendukung kegiatan operasional yayasan dan melindungi para siswa dari berbagai penyimpangan.

Ruang lingkup penelitian ini, meliputi analisis permasalahan yang dihadapi dalam hal keamanan jaringan yang terhubung ke internet meliputi keamanan dari sisi firewall dan proxy, proteksi email, dan pemantauan jaringan. Perlindungan dilakukan untuk melindungi sistem jaringan internal dari ancaman pihak luar. Selain itu, akses pengguna terhadap situs akan dibatasi dari sisi server; Pengembangan aplikasi sistem keamanan jaringan yang mengintegrasikan beberapa tools keamanan jaringan yang telah ada sebagai solusi permasalahan keamanan jaringan; Aplikasi sistem keamanan jaringan ini akan diterapkan pada platform Linux Fedora 5 yang merupakan salah satu distro Linux berstatus open source dan banyak digunakan saat ini sebagai network operating system; Tools keamanan jaringan yang termasuk dalam sistem keamanan yang akan dikembangkan, meliputi Antivirus, Firewall, Mail Filtering, Anti Spam, Web Proxy, dan Intrusion Detection System; Sistem keamanan ini diterapkan pada Yayasan St. Bellarminus yang bergerak pada dunia pendidikan.

Tujuan penelitian adalah mengembangkan sebuah sistem keamanan jaringan menggunakan server berbasis linux pada Yayasan St. Bellarminus dengan mengintegrasikan beberapa fitur keamanan jaringan yang telah ada ke dalam suatu aplikasi berbasis web. Fitur keamanan jaringan yang diintegrasikan, antara lain Firewall, Web Proxy, Intrusion Detection System, Sistem monitoring, dan Mail Filtering.

Manfaat penelitian adalah mengamankan sistem jaringan pada Yayasan St. Bellarminus yang saat ini tidak memiliki keamanan sama sekali dari ancaman yang ada pada jaringan komputer; Dengan mengintegrasikan beberapa fitur keamanan yang ada dan memberikan tampilan pengaturan sehingga mempermudah dalam hal management dan monitoring jaringan; Dan pengaksesan terhadap situs yang dianggap membahayakan dapat dikendalikan.

\section{METODE PENELITIAN}

Perangkat lunak sistem keamanan jaringan dibuat dengan kemampuan dapat memperbaharui fitur keamanan yang ada secara terus menerus sehingga diperlukan pengembangan menggunakan pendekatan metode spiral pada fase putaran yang pertama. Berikut ini adalah - tahap yang ada, yaitu Costumer Communication, Planning, Risk analysis, Engineering, Construction and Release, dan Costumer Evaluation.

\section{TINJAUAN PUSTAKA}

Menurut Stallings (2003:4), arti keamanan jaringan adalah melindungi jaringan tetapi melindungi dalam hal ini adalah masih mempunyai artian luas. Keamanan tidak hanya tentang menjaga orang di dalam jaringan dari dunia luar. Akan tetapi, juga menyediakan akses ke dalam jaringan dengan cara yang dikehendaki, mempersilakan orang di dalam jaringan itu untuk bekerja sama. Ada beberapa elemen tentang keamanan jaringan, yaitu Integrity (data yang diterima sama mestilah sama dengan yang diinginkan), Realibility (data dapat digunakan secara baik tanpa ada halangan), Availability (ketersediaan data jika diperlukan), Security (data yang dikirim maupun yang diterima dilindungi dari akses yang tidak diinginkan).

International Data Corporation (IDC) yang merupakan sebuah perusahaan analisis dan penelitian pasar yang mengkhususkan dalam Teknologi Informasi dan Telekomunikasi, mendefinisikan aplikasi keamanan Unified Threat Management sebagai suatu produk yang menggabungkan dan mengintegrasikan berbagai fitur keamanan menjadi suatu platform hardware tunggal. Kualifikasi dalam kategori ini meliputi kemampuan firewall jaringan, network intrusion detection and prevention (IDP), dan anti-virus gateway. Semua fitur keamanan ini tidak perlu berfungsi secara sempurna tetapi perlu ada dalam produk ini. Dalam kenyataan, perusahaan besar menawarkan layanan terhadap kontrol keamanan yang sangat bervariasi berdasarkan kebutuhan (http://en.wikipedia.org/wiki/ Unified threat management.html). 


\section{PEMBAHASAN}

\section{Sistem yang Sedang Berjalan}

Sistem yang sedang berjalan, yaitu jumlah komputer yang meningkat, baik digunakan untuk bagian administrasi, guru, maupun siswa; Banyaknya perangkat lunak yang digunakan untuk mendukung proses pembelajaran, seperti Microsoft Office, Adobe, dan Macromedia; Penambahan perangkat keras di kelas untuk mendukung proses pembelajaran; Perhatian kepada keaslian sistem operasi; Dan pemasangan akses internet dengan kecepatan tinggi untuk mendukung penggalian informasi di dunia maya.

Yayasan St.Bellarminus memiliki dua jaringan utama, yaitu VLAN 1 dan VLAN 2. Berikut penjelasan dari masing-masing jaringan. Pertama, VLAN 1. VLAN 1 merupakan virtual LAN untuk jaringan guru dan karyawan dengan alamat IP private dengan segment network 193.168.10.0 /24. Kedua, VLAN 2. VLAN 2 merupakan virtual LAN untuk jaringan siswa menggunakan alamat IP private dengan segment network 192.168.10.0 /24. Pada jaringan ini, server juga berfungsi sebagai PC router. Sistem operasi yang dipakai di server saat ini adalah Microsoft Windows Server 2000 sedangkan software yang digunakan agar dapat menjadi PC router adalah Kerio Winroute.

\section{Analisis Permasalahan}

Penggunaan internet sebagai media informasi dan komunikasi yang utama bagi sekolah menimbulkan isu keamanan jaringan internal sekolah dari ancaman dan serangan di internet. Jaringan sekolah perlu mendapatkan proteksi keamanan yang baik agar terlindungi dari ancaman dan serangan di internet sehingga tidak mengganggu kegiatan pembelajaran yang sedang berjalan.

Sistem keamanan yang sekarang digunakan di yayasan St. Bellarminus kurang memberikan pengamanan yang baik dan menyeluruh. Berikut adalah beberapa kekurangan dan kendala yang masih dihadapi sistem keamanan yang sekarang digunakan: Tidak adanya fasilitas network monitoring; Tidak adanya sistem keamanan yang mengantisipasi intrusion; Tidak adanya proxy server; Sumber daya manusia yang tidak berspesialisasi di bidang jaringan; Kurangnya perhatian terhadap masalah keamanan jaringan; Biaya pemeliharaan yang tinggi.

\section{Analisis Pemecahan Masalah}

Peneliti memilih pemecahan masalah melalui pembuatan suatu sistem yang dapat memberikan keamanan yang menyeluruh yang disebut dengan Unified Threat Management (UTM). Kendala yang dihadapi oleh setiap pengguna sistem keamanan jaringan adalah cost dan efficiency/usability. Biasanya yang didapatkan dari sistem dengan cost yang rendah adalah efficiency/usability yang rendah pula. Akan tetapi, hal tersebut tidak menjadi mutlak dalam pengembangan sistem keamanan menggunakan aplikasi open source. Pengembangan ini juga dapat disesuaikan dengan spesifikasi dan kebutuhan sebuah jaringan.

Pada pemilihan fitur keamanan yang dibuat, diacu pada teknologi terbaru saat penelitian ini dibuat, yaitu Network operating system yang digunakan adalah Linux Fedora Core 5 dengan kernel 2.6.18.; Firewall menggunakan iptables versi kernel 2.6.18.; AntiSpam menggunakan SpamAssassin versi 3.1.7.; Database server menggunakan MySQL Server versi 5.0; Web IDE menggunakan PHP versi 5.1.6.; Web Server menggunakan Apache versi 2.0.; IDS menggunakan Snort versi 2.6.1.2.; Proxy Server menggunakan Squid 2.5; Antivirus menggunakan ClamAV 0.88.7.

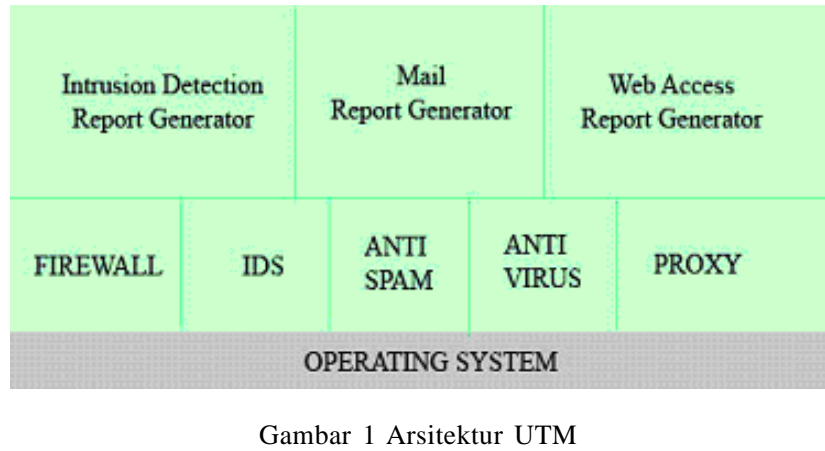

Alasan penggunaan kesemua aplikasi tersebut adalah karena aplikasi tersebut mudah untuk di-update melalui tool Linux, Yum Updater, dan merupakan aplikasi open source.

\section{Perancangan Sistem}

Pengembangan sistem solusi yang akan dilakukan pada platform Linux Fedora 5 yang merupakan salah satu distro Linux berstatus open source dan banyak digunakan saat ini sebagai network operating system. Sistem solusi ini akan menggabungkan beberapa fitur keamanan jaringan yang telah ada ke dalam suatu aplikasi yang berbasiskan web. Bahasa pemrograman yang dipilih adalah PHP sedangkan web server yang digunakan 
adalah Apache. Untuk database server, digunakan MySQL.

Untuk segi keamanan, digunakan beberapa cara: Memakai store procedure untuk mencegah SQL injection; Pengunaan session pada data; Tiap halaman dibuat validasi pengecekan session; Semua parameter yang diinput dilakukan validasi, data yang tidak sesuai akan ditolak; Semua validasi akan dijalankan di sisi server; Password pengguna akan dienkripsi dengan modul MD5.

\section{Perancangan Fitur Sistem Solusi}

Sistem solusi yang baru akan memiliki beberapa fitur sebagai berikut. Pertama, Firewall. Firewall digunakan untuk mengontrol akses dari internet ke jaringan internal dan dari jaringan internal ke internet. Aplikasi yang digunakan adalah aplikasi iptables yang langsung terdapat pada Linux Fedora Core 5. Kedua, Web Proxy. Web proxy digunakan untuk caching proxy server dan pembatasan hak akses ke internet. Aplikasi yang digunakan adalah aplikasi squid sebagai proxy controller dan SARG (Squid Analysis Report Generator) sebagai HTMLbased proxy report generator. Ketiga, Intrusion Detection System(IDS). Intrusion Detection System digunakan untuk menangkap intruder atau penyusup jaringan. Aplikasi yang digunakan adalah aplikasi snort sebagai IDS controller dan ACID (Analysis Console for Intrusion Detection) sebagai HTML-based IDS report generator. Keempat, Mail Filtering. Mail Filtering digunakan untuk scan dan filter setiap e-mail yang masuk atau keluar dari domain jaringan. Aplikasi yang digunakan adalah qmail scanner yang diintegrasikan dengan clamAV sebagai antivirus dan spamassassin sebagai Anti Spam sedangkan untuk HTML-based mail report generator digunakan isoqlog (Lihat Gambar 2).

\section{Implementasi}

Jika nama user dan password benar maka administrator dapat mengakses sistem dengan tampilan awal di halaman home (Lihat Gambar 4).



Gambar 2 Perancangan Fitur Sistem Solusi

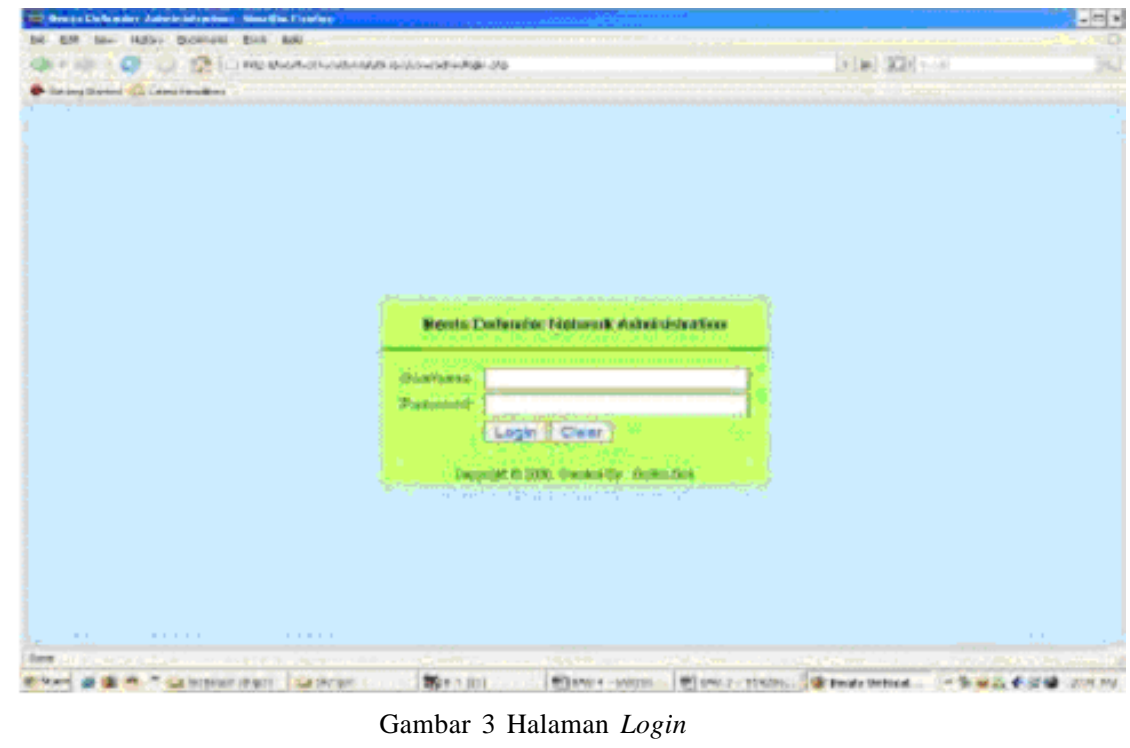




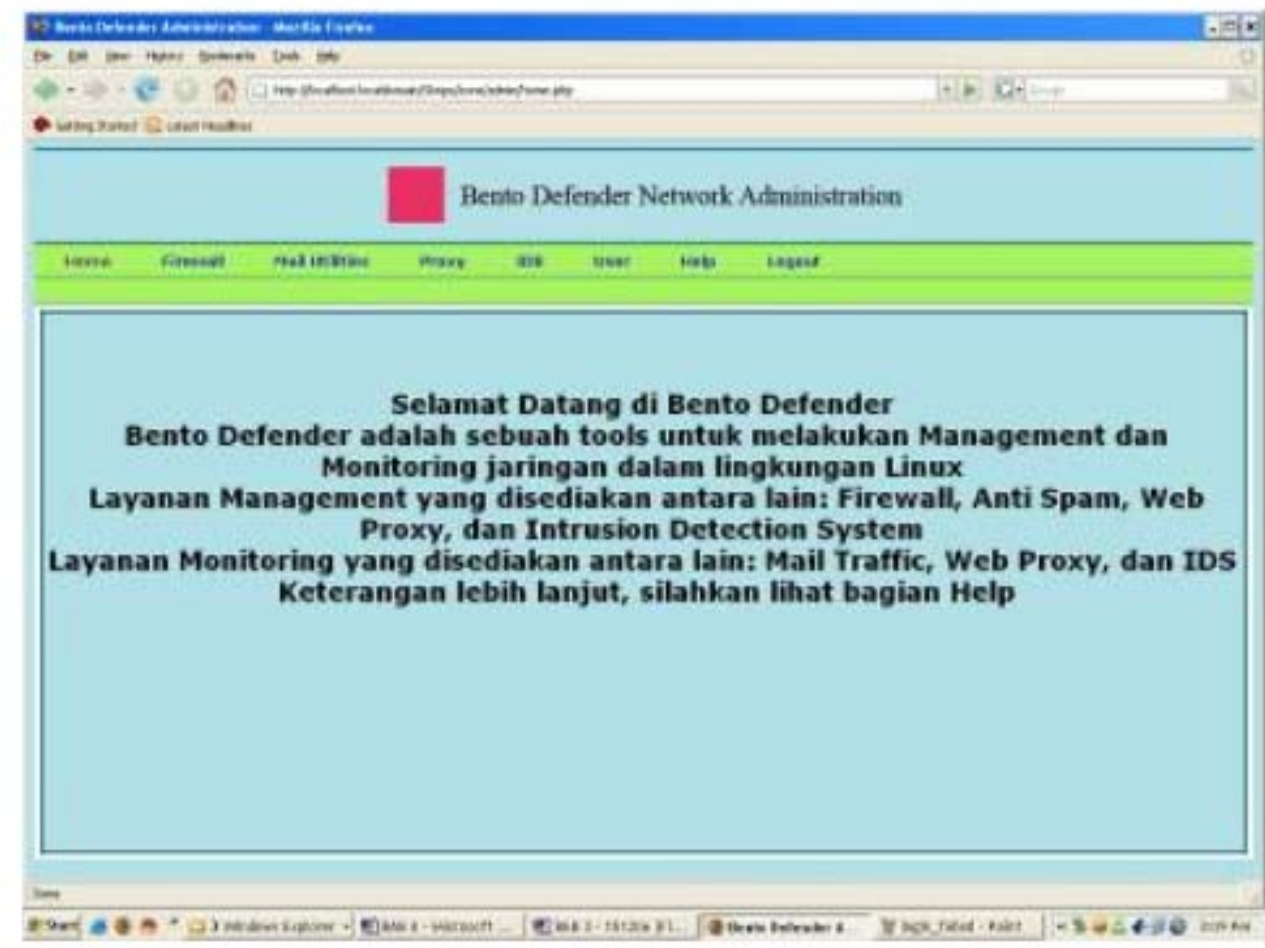

Gambar 4 Halaman Home

Administrator dapat mulai menggunakan sistem dari pilihan menu yang tersedia: Firewall, Mail Utilities, Proxy, IDS, User, Help, dan Logout. Jika membuka menu Firewall, administrator dapat melihat rule-rule firewall yang telah ditambahkan (rule ini tidak termasuk rule yang sudah ada dalam sistem ketika Linux di-install) (Lihat Gambar 5).

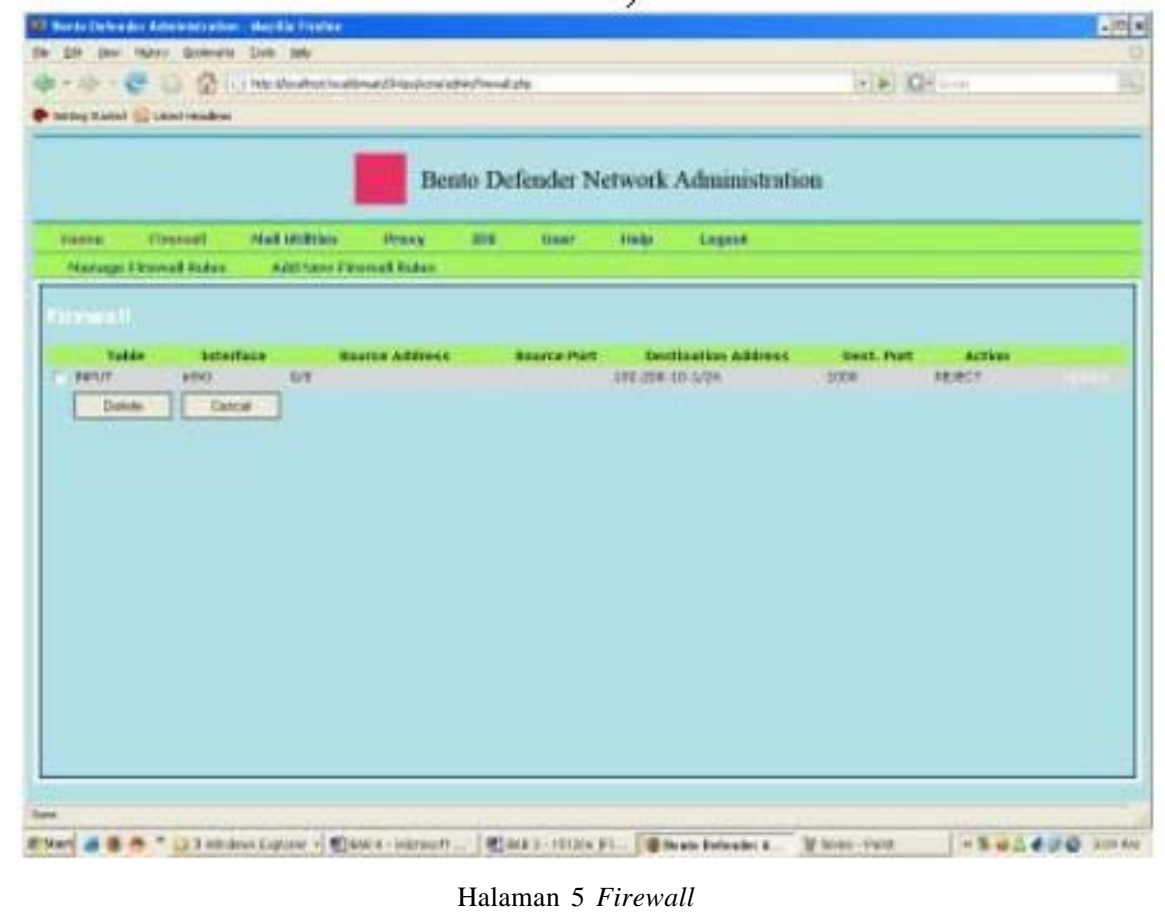


Submenu yang ditampilkan adalah Manage Firewall Rules dan Add New Firewall Rules. Jika ingin menambahkan rule dalam firewall, administrator dapat memasukkannya di halaman Add New Firewall Rules atau jika ingin mengubah rule dalam firewall, administrator dapat melakukannya di halaman Add NewFirewall Rules dengan parameter yang sudah terisi (Lihat Gambar 6).
Rule dapat dihapus dari halaman Manage Firewall Rules melalui tombol 'Delete'. Dari pilihan menu utama, administrator dapat melihat data pengiriman e-mail di menu Mail Utilities (Lihat Gambar 7).

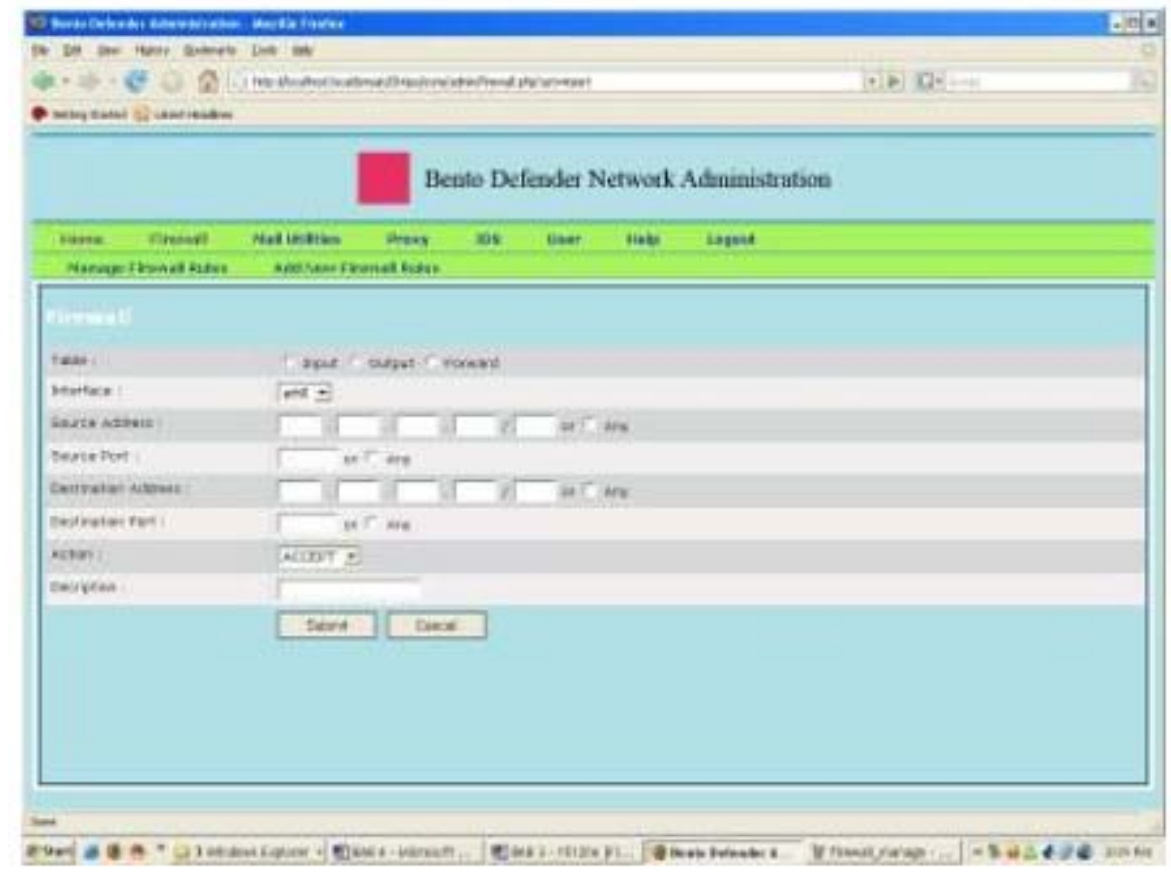

Gambar 6 Halaman Menambah dan Mengubah Rule Firewall
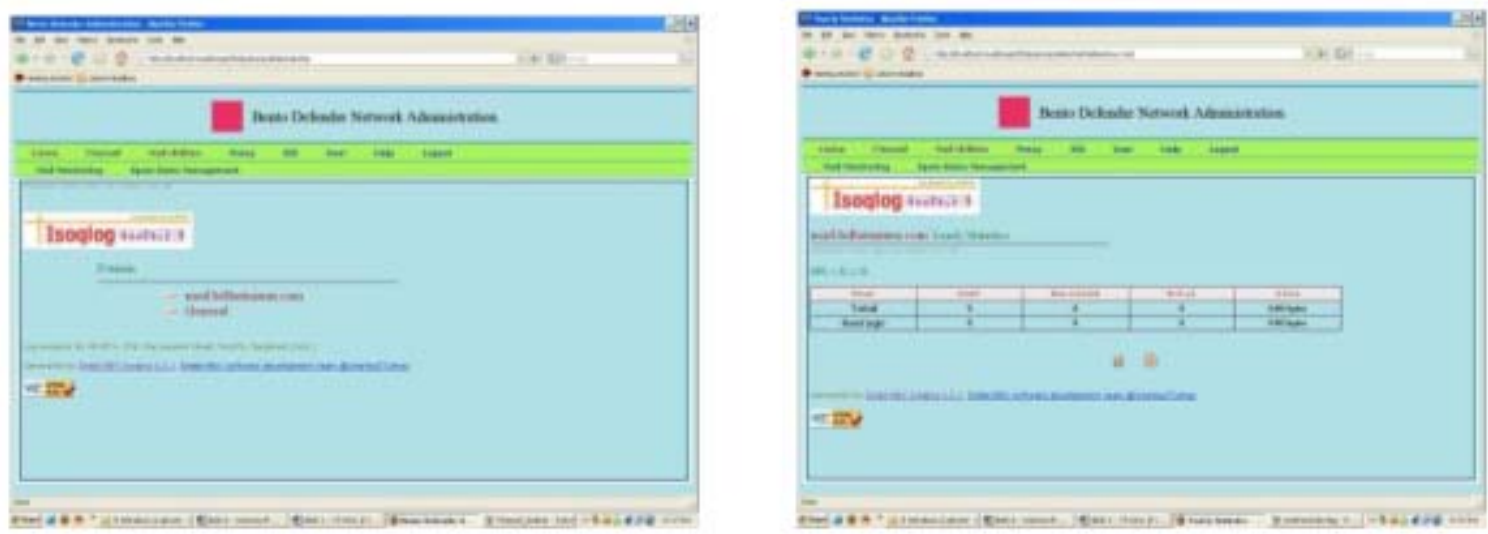

Gambar 7 Halaman isoqlog 
Jika administrator memilih Spam Rules Management maka administrator dapat mengatur rule untuk kriteria spam (Lihat Gambar 8).
Submenu yang ditampilkan sama seperti halaman Firewall dan fiturnya sama seperti Firewall. Jika administrator memilih Proxy maka administrator dapat melihat data para pengguna jaringan dalam lingkup harian, mingguan, dan bulanan (Lihat Gambar 9).

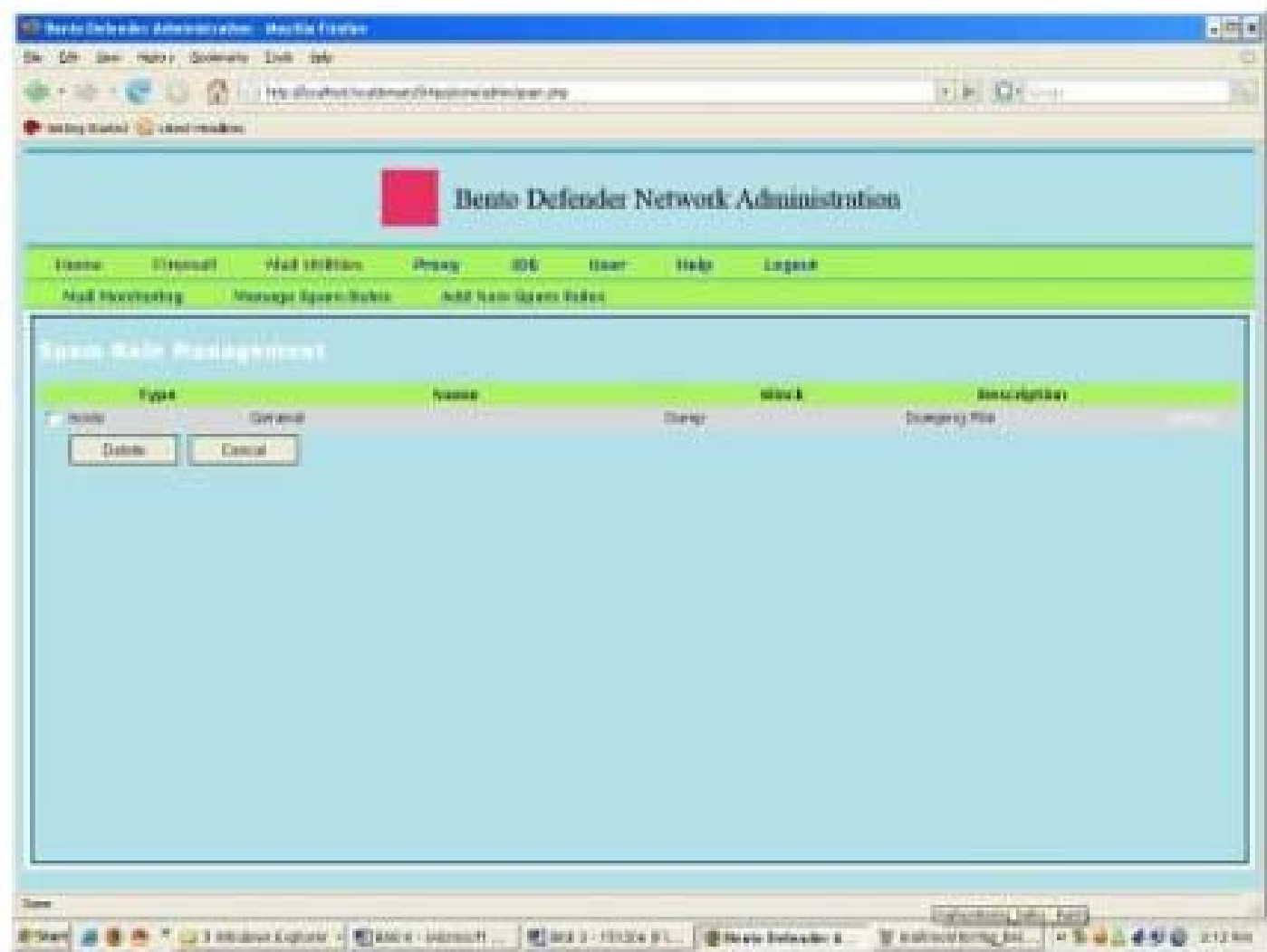

Gambar 8 Halaman Spam
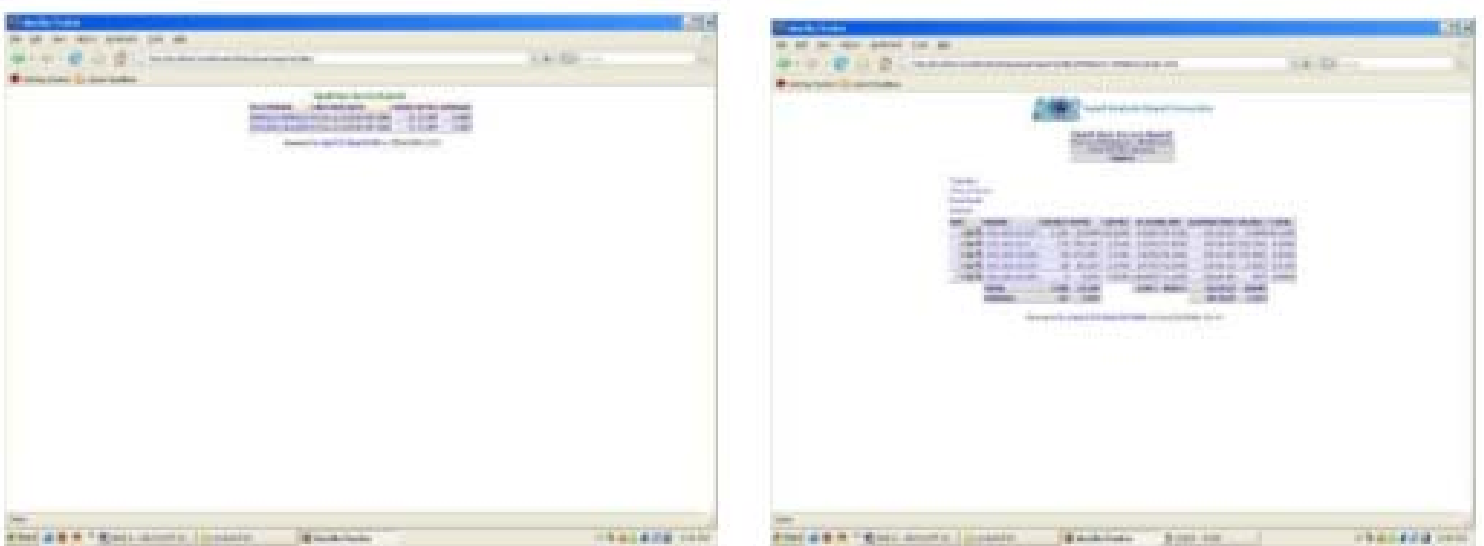

Gambar 9 Halaman sarg 
Jika administrator memilih Proxy Rules Management maka administrator dapat mengatur rule untuk membatasi situs dan akses pengguna jaringan (Lihat Gambar 10).
Submenu yang ditampilkan sama seperti halaman Firewall dan fiturnya sama seperti Firewall. Jika administrator memilih IDS maka administrator dapat melihat data intrusion yang tercatat dalam sistem (Lihat Gambar 11).

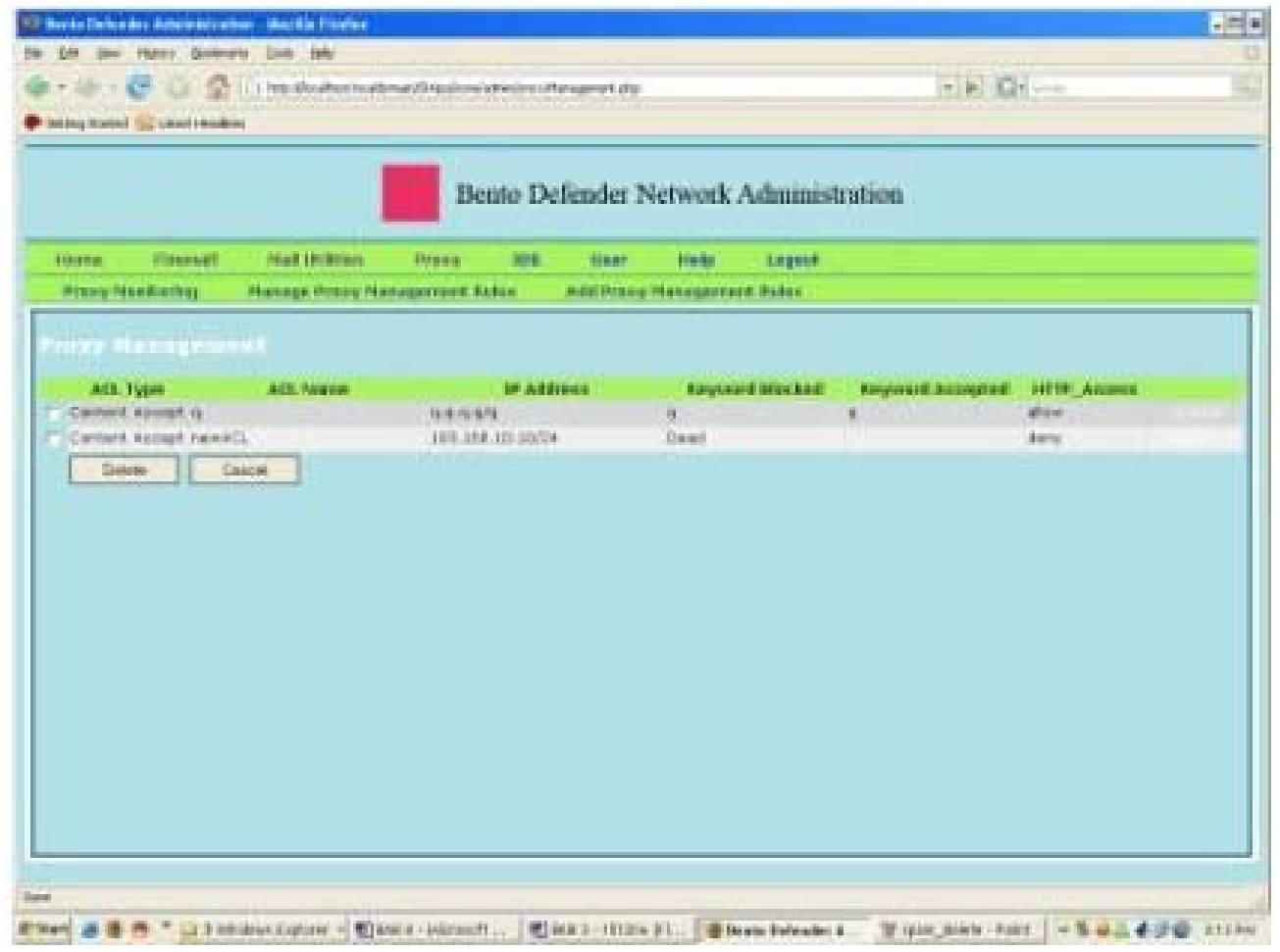

Gambar 10 Halaman Proxy Management

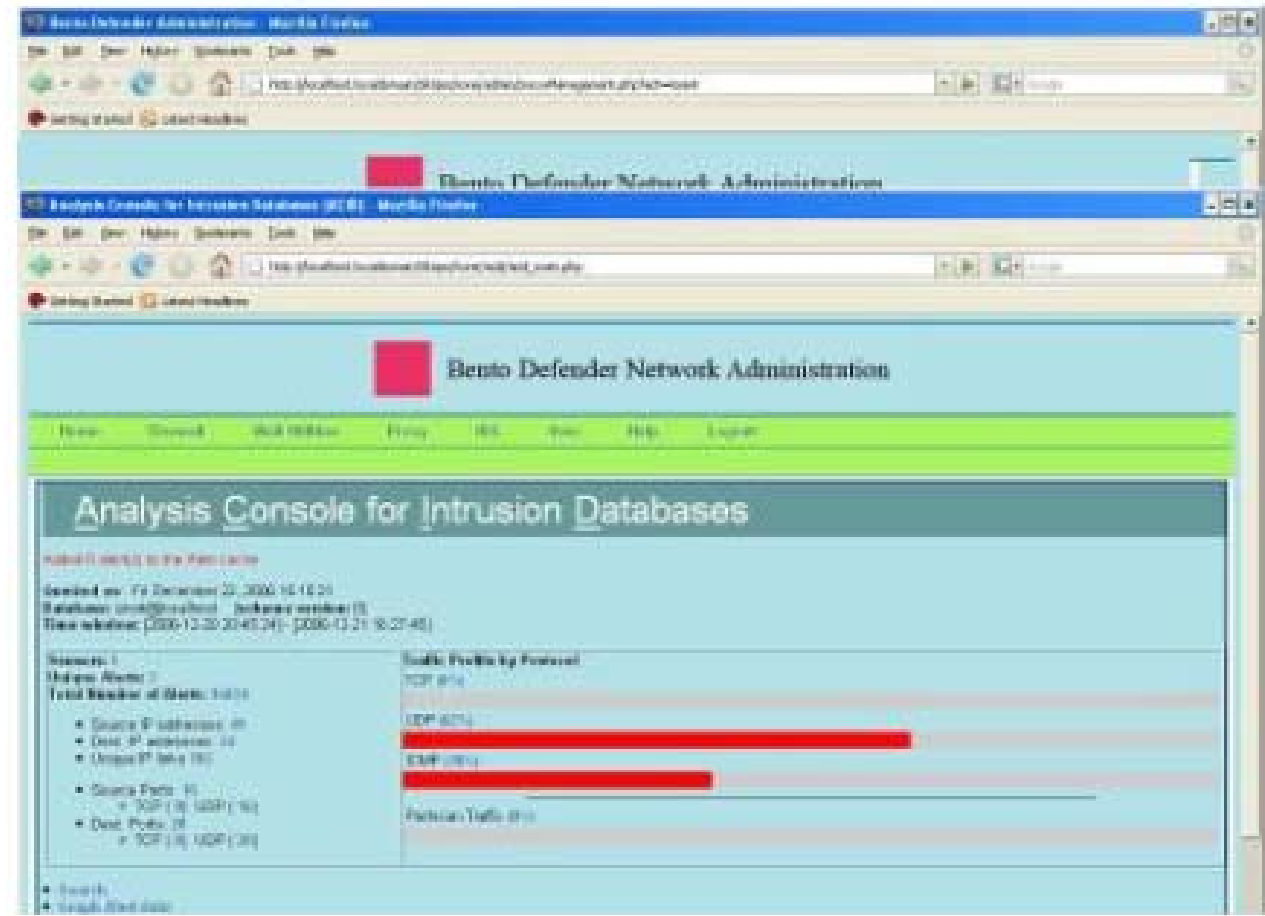

Gambar 11 Halaman ACID 
Jika administrator memilih User maka administrator dapat melakukan penambahan, penghapusan, dan pengubahan pengguna sistem (Lihat Gambar 12).
Submenu yang ditampilkan adalah Manage, Delete, dan Add New. Jika ingin menambahkan user yang dapat mengakses sistem, administrator dapat memasukkannya di halaman Add New. Jika administrator memilih Help maka administrator dapat melihat petunjuk penggunaan sistem Bento Defender (Lihat Gambar 13).

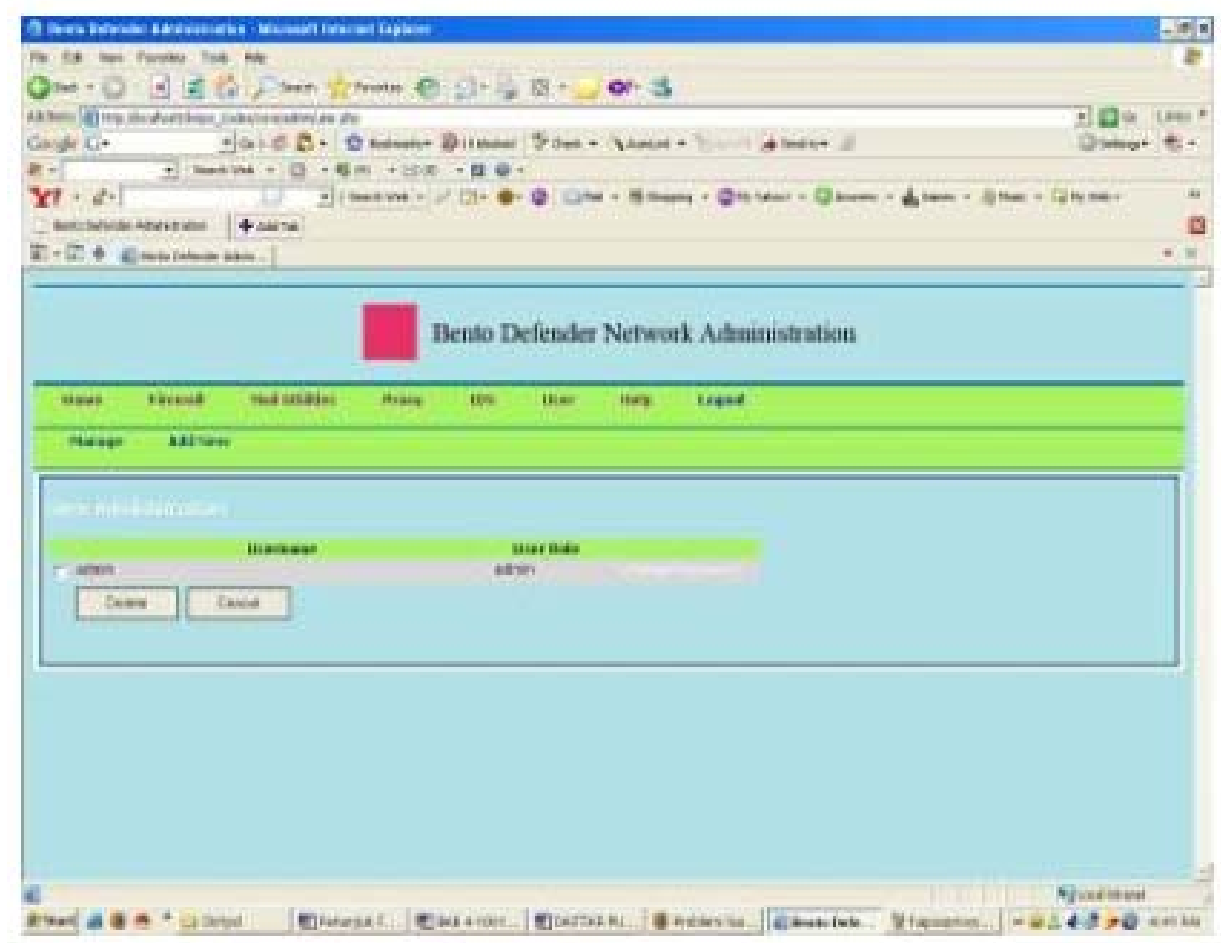

Gambar 12 Halaman User

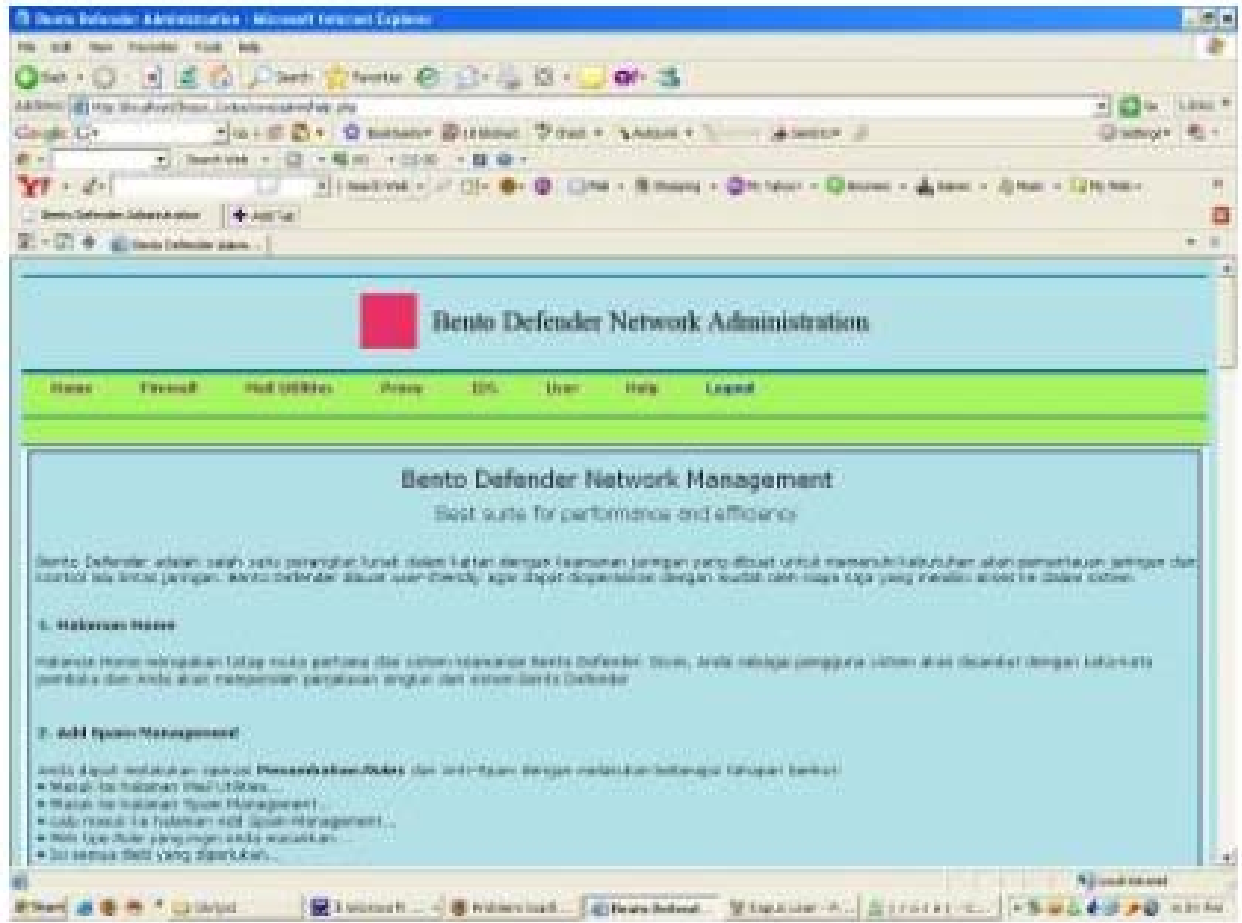

Gambar 13 Halaman Help 
Jika administrator ingin mengakhiri administrasi sistem, administrator harus memilih Logout dengan menjawab Yes (Lihat Gambar 14).

\section{Evaluasi Kemampuan Fitur Sistem}

Untuk mengukur kinerja sistem, diadakan beberapa pengujian terhadap tools yang digunakan. Pengujian yang dilakukan, antara lain sebagai berikut. Pertama, pengujian dengan mengirimkan email Spam (Lihat Tabel 1).

Dari data di atas, didapatkan rata-rata ketepatan penyaringan Spam senilai:

$$
\begin{aligned}
& =(90+100+90+95+85): 5 \\
& =92.50 \%
\end{aligned}
$$

Jadi, rata-rata persentase ketepatan penyaringan email yang mengandung Spam adalah $92.50 \%$ sedangkan sebesar $7.50 \%$ ketidaktepatan pemfilteran disebabkan oleh padatnya lalu lintas jaringan dan banyaknya email yang masuk dalam satu satuan waktu. Kedua, pengujian dengan mengirimkan email dengan attachment Virus (Lihat Tabel 2).

Dari data di atas, didapatkan rata-rata ketepatan pendeteksian email bervirus senilai:

$$
\begin{aligned}
& =(100+100+98.33+96.67+96): 5 \\
& =98.20 \%
\end{aligned}
$$

Jadi, rata-rata persentase ketepatan pendeteksian email bervirus adalah $98.20 \%$ sedangkan sebesar $1.80 \%$ ketidaktepatan pendeteksian disebabkan oleh banyaknya client yang dikirimi virus. Dari hasil ini, dapat ditarik simpulan bahwa Anti Virus ClamAV menunjukkan kinerja yang menurun dalam intensitas email y ang tinggi tetapi masih dalam batas yang dapat ditolerir.

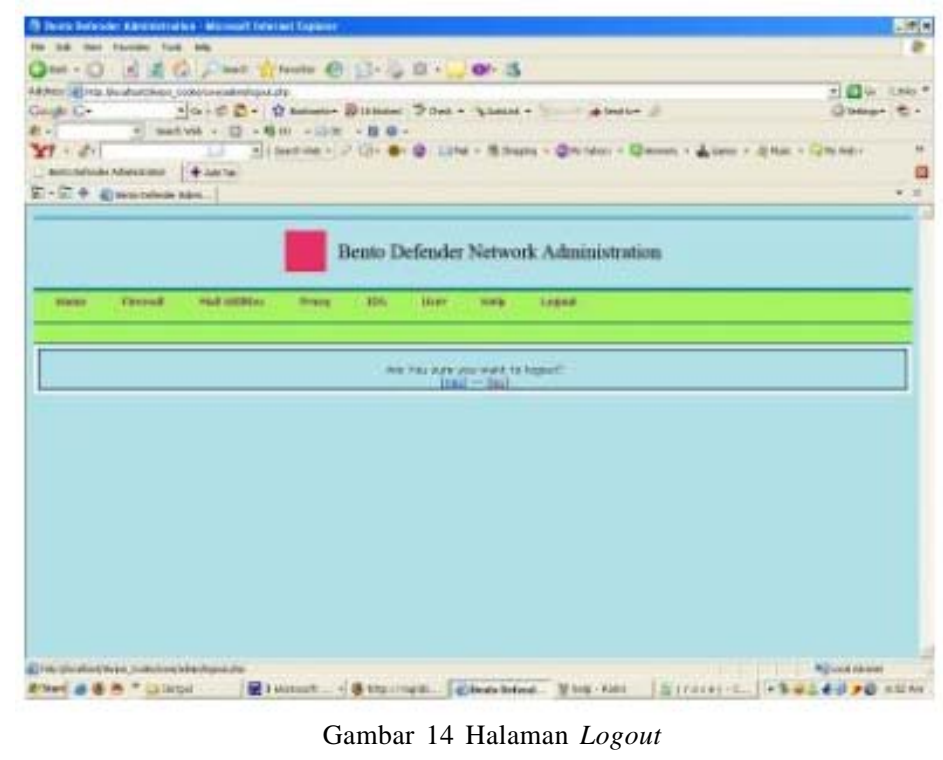

Tabel 1 Hasil Pengujian Penyaringan Spam

\begin{tabular}{|c|c|c|c|c|}
\hline No. & Kata-Kata & Email ditolak & Email terkirim & Persentase \\
\hline 1 & SPAM & 18 & 2 & 90 \\
\hline 2 & PORN & 20 & 0 & 100 \\
\hline 3 & SEX & 18 & 2 & 90 \\
\hline 4 & WXX & 19 & 1 & 95 \\
\hline 5 & DRUGS & 17 & 3 & 85 \\
\hline
\end{tabular}

Tabel 2 Hasil Pengujian Pengiriman Email Bervirus

\begin{tabular}{|c|c|c|c|c|}
\hline No. & Jum lah email & Email ditolak & Email terkirim & Persentase \\
\hline 1 & 20 & 20 & 0 & 100 \\
\hline 2 & 45 & 45 & 0 & 100 \\
\hline 3 & 60 & 59 & 1 & 98.33 \\
\hline 4 & 120 & 116 & 4 & 96.67 \\
\hline 5 & 150 & 144 & 6 & 96 \\
\hline
\end{tabular}


Ketiga, pengujian rule firewall dan proxy. Pengujian ketepatan rule firewall dan proxy dilakukan dengan menambah rule baru di port yang biasa digunakan seperti port 80 (HTTP) dan 25 (TELNET). Dan dilakukan penutupan semua port dan alamat tujuan. Setelah itu, dilakukan akses dari komputer client ke situs sembarang dan menghasilkan laporan berikut.

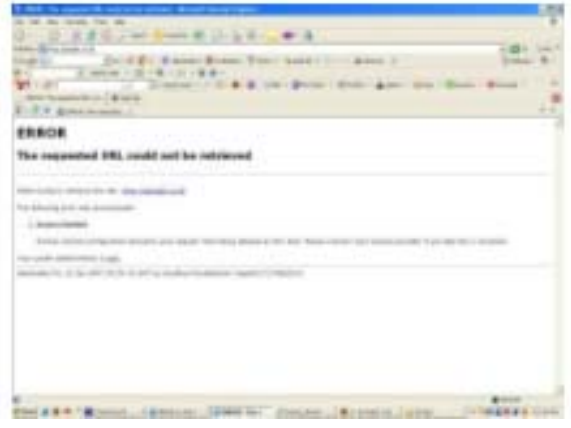

Tampilan pembatasan akses situs

\section{Evaluasi dari Sisi Teknis dan Kelebihan}

Pada Tabel berikut, disajikan informasi mengenai perbandingan sistem keamanan jaringan dari beberapa vendor dengan sistem keamanan Bento Defender (Lihat tabel 3).

Berdasarkan hasil wawancara dengan staf IT yang menggunakan aplikasi ini, didapat hasil evaluasi secara menyeluruh sebagai berikut: Dengan adanya aplikasi Bento Defender, akses kepada situs yang tidak layak dapat dibatasi; Staf IT dapat melakukan pemantauan terhadap aktivitas jaringan, baik yang bersih atau mengandung ancaman; Pembaharuan versi tools Bento Defender dapat dilakukan dengan mudah melalui Yum Updater; Pengaturan terhadap tools keamanan yang ada dapat dilakukan lebih mudah karena tools tersebut diintegrasikan dan ditampilkan dalam tatap muka yang bersifat user-friendly; Jika diukur dari satuan
Kinerja/Harga, kemampuan Bento Defender termasuk bernilai 80 dari 100; Staf masih mengalami kesulitan dalam melakukan pembaharuan antivirus database definition karena masih harus menggunakan sintaks konsol fresclam; Kurang terbiasanya staf dalam lingkungan Linux serta tampilan antarmuka yang standar (web interface) menjadikan staf jenuh; Dan secara keseluruhan, aplikasi ini sangat membantu Yayasan St. Bellarminus dalam hal kontrol dan konfigurasi jaringan.

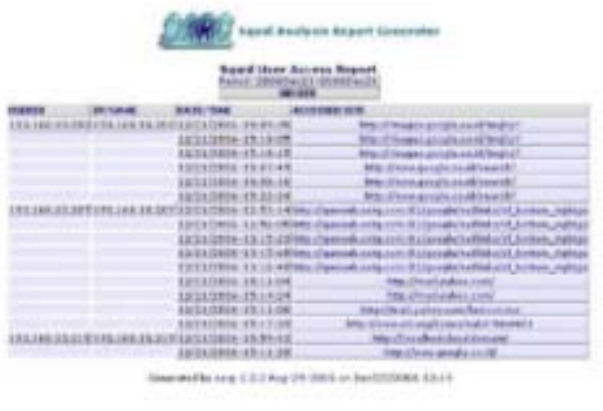

Tampilan Proxy Monitoring > Denied Reports

\section{PENUTUP}

Dari hasil penelitian yang telah dilakukan, dapat ditarik beberapa simpulan sebagai berikut. Pertama, suatu sistem komputer yang terhubung jaringan dengan memiliki kepentingan khusus, harus lebih memperhatikan keamanan datanya, terlebih untuk yayasan St. Bellarminus yang menggunakan fasilitas internet untuk mendukung kegiatan belajar mengajar. Kedua, aplikasi keamanan jaringan yang ada saat ini sangat beragam, mulai dari firewall, antivirus, proxy, mail scanner, dan sebagainya. Hal itu dapat merumitkan dalam hal pengaturan aplikasi dan dibutuhkan staf yang ahli pada bidang jaringan. Ketiga, dengan adanya Unified Threat Management (UTM), kerumitan dalam hal pengaturan aplikasi akan berkurang disebabkan

Tabel 3 Evaluasi Perbandingan Sistem

\begin{tabular}{|c|c|c|c|}
\hline Feature & $\begin{array}{c}\text { Equiinet UTMTotal } \\
\text { Protection }\end{array}$ & $\begin{array}{c}\text { Watchguard Firebox } \\
\text { x core xi2soe UnM } \\
\text { Solution }\end{array}$ & Bento Defender \\
\hline Hardware Based & - & $\sqrt{ }$ & $\sqrt{ }$ \\
\hline Software Based & $\sqrt{ }$ & - & - \\
\hline Web Based & $\sqrt{ }$ & - & $\sqrt{ }$ \\
\hline Anti-Spam & $\sqrt{ }$ & $\sqrt{ }$ & $\sqrt{ }$ \\
\hline Anti-Virus & $\sqrt{ }$ & $\sqrt{ }$ & $\sqrt{ }$ \\
\hline Upgrade & $\checkmark$ (dengan biay a) & $\sqrt{ }$ & $\sqrt{ }$ (per tools) \\
\hline $10 S$ & - & $\sqrt{ }$ & $\sqrt{ }$ \\
\hline Gigabit LAN & - & $\sqrt{ }$ & $\sqrt{ }$ \\
\hline License & 1 tahun & 1 tahun & 1 tahun \\
\hline Price & $\$ 1,494.00$ & $\$ 7,297.50$ & free (for the first) \\
\hline
\end{tabular}


pengaturan sebagian besar dari aplikasi digabung menjadi satu kesatuan (dalam web).

Keempat, UTM dapat diatur melalui program administrasi berbasiskan web sehingga dapat dilakukan oleh komputer lain melalui web browser. Kelima, UTM yang dibuat oleh peneliti memiliki tingkat biaya yang lebih rendah dibandingkan dengan UTM yang telah ada serta tidak memerlukan biaya untuk sistem operasi server karena UTM yang dibuat peneliti berjalan di sistem operasi open source, yaitu Linux Fedora Core 5. Selain itu, keuntungan yang didapatkan dari aplikasi UTM yang dibuat adalah kemampuan untuk melakukan pembaharuan versi yang mudah dan tidak terpaku dengan hanya satu sistem operasi (multi-platform). Keenam, aplikasi Bento Defender sebagai UTM yang dibuat peneliti sangat membantu yayasan St. Bellarminus dalam hal kontrol dan proteksi jaringan. Proxy membatasi akses pengguna dalam web. Firewall membantu membatasi akses pengguna terhadap alamat IP dan port yang diperuntukkan bagi pengguna khusus. IDS memberikan laporan penyusupan yang terjadi dalam sistem sehingga keputusan dapat diambil secepatnya serta mail management memberikan proteksi terhadap email bervirus dan yang mengandung spam.

Saran yang dapat diberikan untuk pengembangan sistem serupa agar menjadi lebih baik lagi di masa mendatang, antara lain Tools keamanan jaringan yang digunakan sebaiknya di-update secara berkala; Penggunaan distro Linux sangat diajurkan mengingat efisiensi yang dihasilkan oleh distro ini sangat tinggi; Selalu mencari informasi perkembangan teknologi yang ada pada tools yang digunakan dan melakukan upgrade pada tools tersebut. Aplikasi ini masih dapat digunakan atau diperbaharui untuk versi upgrade terbaru; Diperlukan sistematika backup agar sistem yang dipakai tetap dapat berjalan bila terjadi suatu masalah; Peningkatan kualitas perangkat keras yang digunakan sangat disarankan mengingat semakin tinggi spesifikasi perangkat keras siste, maka kinerja, performa, kapasitas pengguna (komputer), dan daya tahan sistem akan semakin meningkat; Fitur keamanan jaringan masih dapat ditambahkan, seperti secure dns dan lain sebagainya; Berdasarkan hasil pengamatan bahwa masih adanya kelemahan dalam proses pendeteksian virus oleh sistem ini maka disarankan agar setiap pengguna (komputer) tetap memiliki anti virus internal; Diperlukan suatu laporan yang terintegrasi untuk memantau semua kegiatan jaringan. Laporan tersebut diperuntukkan bagi petinggi yayasan yang ingin melihat laporan dengan format yang menyeluruh dan mudah dimengerti.

\section{DAFTAR PUSTAKA}

Anonymous. 2006. http://id.wikipedia.org/wiki/Linux .2006. http://qmail-scanner.sourceforge.net/

Bragg, Roberta.2004. The Complete Reference Network Security. New York: McGraw-Hill.

Connolly, Thomas and Carolyn Begg. 2005. Database Systems: A Practical Approach to Design, Implementation, and Management. New York: McGraw-Hill.

Ramakrishnan, Raghu and Johannes Gehrke. 2003. Database Management Systems. New York: McGraw-Hill.

Comer, Douglas E. 1999. Computer Networks and Internets 2nd Edition. New Jersey: Prentice-Hall.

Kurose, James F. 2003. Computer Networking, A Top-Down Approach Featuring the Internet 2nd Edition. Boston: Addison Wesley.

Norton, Peter. 1999. Complete Guide to Networking. Indiana: SAMs Publishing.

Stallings, William. 2003. Cryptography and Network Security: Principles and Practice. New Jersey: Prentice-Hall.

Syukri, Muhammad. 2002. PC Router dengan GNU/Linux. Jakarta: Elex Media Komputindo.

Tanenbaum, Andrew S. 2003. Computer Networks 4th Edition. New Jersey: Prentice-Hall. 